\author{
Wojciech J. Kosior \\ University of Rzeszów \\ ORCID: 0000-0002-4710-4523 \\ wjkosior@ur.edu.pl
}

\title{
Age Limits in the Service of the Roman Army - lex Aelia Sentia and lex Visellia
}

\author{
Granice wieku w służbie armii - lex Aelia Sentia i lex Visellia
}

\begin{abstract}
SUMMARY
In ancient Rome at the beginning of the first century A.D., a number of reforms in the field of personal rights were carried out. At that time, the lex Aelia Sentia was passed, which limited the liberation of slaves. During this period, lex Visellia also was passed, which tempted former slaves with Roman citizenship in exchange for serving in the army. The purpose of this article was an attempt to determine whether it can be said that the title acts, i.e. lex Aelia Sentia and lex Visellia, have a common goal and, in fact, part of their records together created one legal concept that was to ensure easy access of recruits to the newly formed paramilitary organisation militia vigilum, to which, after the civil war and general recruitment crisis in the army, there were no volunteers.
\end{abstract}

Keywords: lex Aelia Sentia; lex Visellia; vigiles; Latini iuniani

I.

At the beginning of the first century A.D., Octavian Augustus conducted a series of very extensive reforms in the field of private law in the Roman state, which significantly affected social, personal and family relationships. One of the aspects that was covered by the reformist activity of the first princeps was the liberation of slaves, the scale of which was then limited. Among others, lex Aelia Sentia was to serve this purpose modified the triggering procedure itself and set some restrictions by introducing to the premises of effective legal liberation the requirement to achieve a specific age. This regime concerned both the slave and the owner. As 
a rule, the slave could be liberated in such a way that after the liberation he became a Roman citizen if he was at least 30 years old when he obtained his freedom, and the owner acquired the right to self-release only after reaching the age of 20. Certain deviations from this requirement were possible, but only after obtaining the consent of the competent council and after proving the just cause of liberation. As a rule, when a slave was liberated below this age, he became Junian Latin - a person who is actually free but without political rights. A number of legal options were provided for such people, through which they could apply for Roman citizenship. One of these options was regulated by lex Visellia, passed after the Aelia Sentia act, which provided for the granting of citizenship for the Junian Latins, who for six years served as military vigiles in Rome.

The purpose of this article is to try to determine if it can be said that the title acts, that is lex Aelia Sentia and lex Visellia, combined a common goal and, in fact, a part of their entries together created one legal concept, which was to ensure easy access of recruits to the newly formed paramilitary organisation militia vigilum, to which, after the civil war and general recruitment crisis in the army, there were no volunteers.

The idea of bending over such a question emerged in my case as a result of widely conducted research on the age limits occurring in Roman law, which I devoted to my doctoral dissertation ${ }^{1}$. In my work, among other things, I considered the reasons for introducing the mentioned 30-year limit in the Aelia Sentia law, which does not appear in any other Roman sources of private law. In addition, a less-known view expressed in the 1960s prompted me to look at these two laws together, by the historian of antiquity, prof. K.M.T. Atkinson from the Queen's University of Belfast, which, among other things, investigated the reasons for the reform of the liberation carried out by Octavian Augustus and most exposed the military reason for these changes, suggesting that the Aelia Sentia and Visellia laws should be interpreted together ${ }^{2}$.

The hypothesis in this article is, therefore, whether we can talk about the fact that, as a result of wars and the crisis of the Roman army, Octavian Augustus encountered a problem with those willing to serve in the paramilitary organisation he created. The laws led to the creation of a new social group of Junian Latins, located in "a legal vacuum", who, in order to obtain the desired Roman citizenship, decided to serve as vigiles. Then we could talk about a regnum per legem rule, and about the existence of the legal and political concept of the princeps, who could skillfully use it.

I W.J. Kosior, Kategorie i granice wieku oraz ich znaczenie w prawie rzymskim, Warszawa 2018 (unpublished doctoral dissertation).

2 K.M.T. Atkinson, The Purpose of the Manumission Laws of Augustus, "Irish Jurist" 1966, Vol. 1, pp. 356-374. 
II.

The first of the title acts, lex Aelia Sentia, was established in 4 A.D. ${ }^{3}$ and it was part of the extensive reforms introduced by Octavian Augustus. As M. Zabłocka rightly pointed out, writing about the general causes of these reforms, the first princeps took advantage of the fatigue of Roman society caused by long-lasting civil wars and widespread uncertainty ${ }^{4}$. In such conditions, he appeared with the slogan of restoring peace, order and the old Republican system. He also sought to revive the Romanitas by resurrecting the customs, religion, and morals. He tried to strengthen the position of old Roman families and at the same time to curb the uncontrolled growth of new citizens due to mass slave liberation.

In the case of this law, the measure used to limit the scale of the releases was the age criterion. Namely, in this act there were introduced two age limits which the liberating and the liberated had to achieve, that from a formal point of view, liberation was fully valid and effective, it is to end with obtaining Roman citizenship. And so the owner who wanted to grant freedom had to be over 20, and the slave -30 years. From the point of view of the considerations discussed here, the most important is the solution adopted in relation to the slave, of which Gaius bluntly wrote:

G. 1,17: Nam in cuius personam tria haec concurrunt, ut maior sit annorum triginta et ex iure Quiritium domini et iusta ac legitima manumissione liberetur, id est uindicta aut censu aut testamento, is ciuis Romanus fit; sin uero aliquid eorum deerit, Latinus erit ${ }^{5}$.

Above were mentioned the requirements that had to be fulfiled for the slave to become a Roman citizen. For this purpose, three premises had to coincide: the slave had to have more than 30 years at the moment of liberation, had to belong to its owner under the law of the Quirites and the liberation had to take place on the basis of civil law regulated by statutes, it had to be delivered by a rod or staff called vindicta (manumissio vindicta), by entering the list of citizens (manumissio censu) or by a way of will (manumissio testamento). As a rule only with the three requirements being met, the liberated became a Roman citizen. Certain exceptions were also provided from these disciplines ${ }^{6}$.

3 Cf. W. W. Buckland, The Roman Law of Slavery: The Condition of the Slave in Private Law from Augustus to Justinian, Cambridge 1908, p. 535, 537.

4 M. Zabłocka, Przemiany prawa osobowego i rodzinnego w ustawodawstwie dynastii julijsko-klaudyjskiej, Warszawa 1987, p. 13.

5 Cf. also: Epit. Ulp. 1,12; Eadem lege cautum est, ut minor triginta annorum servus vindicta manumissus civis Romanus non fiat, nisi apud consilium causa probata fuerit; ideo sine consilio manumissum caesaris servum manere putat. Testamento vero manumissum perinde haberi iubet, atque si domini voluntate in libertate esset. ideoque Latinus fit.

6 Namely, slaves under the age of 30 could become Roman citizens after liberation, only if the owner made a liberation with a staff (manumissio vindicta) after showing the so-called just cause of 
If, however, none of the exceptions provided for occurred, and the slave was liberated despite not meeting the requirements of the act (in this age), then he became a Junian Latin. This meant that the freedman acquired legal freedom, but without Roman citizenship. He had commercium with the Romans, but he did not have the ability to make a will or obtain anything from the will ${ }^{7}$. He could not leave a heritage for his successors, because such property fell to his former owner in the form of peculium, in other words, the situation looked as if liberation never occurred. A Junian Latin was also deprived of the right to enter into a valid Roman

liberation (iusta causa manumissionis) and if the reason has been proved before the competent council (consilium). Similarly, a slave who was under 30 years old could have obtained Roman citizenship by liberation, if he was liberated by way of a will and if he was left as a liberated heir by an insolvent owner. Cf. G. 1,18; Quod autem de aetate serui requiritur, lege Aelia Sentia introductum est. nam ea lex minores XXX annorum seruos non aliter uoluit manumissos ciues Romanos fieri, quam si uindicta, apud consilium iusta causa manumissionis adprobata, liberati fuerint. The just reasons for the liberation are listed below: G. 1,19; Iusta autem causa manumissionis est, ueluti si quis filium filiamue aut fratrem sororemue naturalem aut alumnum aut paedagogum aut seruum procuratoris habendi gratia aut ancillam matrimonii causa apud consilium manumittat, G. 1,39; Iustae autem causae manumissionis sunt, ueluti si quis patrem aut matrem aut paedagogum aut conlactaneum manumittat. sed et illae causae, quas superius in seruo minore XXX annorum exposuimus, ad hunc quoque casum, de quo loquimur, adferri possunt. item ex diuerso hae causae, quas in minore XX annorum domino rettulimus, porrigi possunt et ad seruum minorem XXX annorum. For the just reason for the liberation (iusta causa manumissionis) the act recognized the situations when the liberation concerned father, mother, son, daughter, brother, including the half-brother, sister, student, teacher. The just reason was also the liberation of a slave to be the property manager and to free the slave to marry her. See also G. 1,20; Consilium autem adhibetur in urbe Roma quidem quinque senatorum et quinque equitum Romanorum puberum, in prouinciis autem uiginti recuperatorum ciuium Romanorum. idque fit ultimo die conuentus; sed Romae certis diebus apud consilium manumittuntur. maiores uero triginta annorum serui semper manumitti solent, adeo ut uel in transitu manumittantur, ueluti cum praetor aut pro consule in balneum uel in theatrum eat. The council (consilium) before which liberation took place in Rome consisted of 5 senators and 5 equites in adulthood, and in the provinces of 20 recuperates who were Roman citizens. Cf. T. Giménez-Candela, Bemerkungen über Freilassungen in consilio, „Zeitschrift der Savigny-Stiftung für Rechtsgeschichte: Romanistische Abteilung“ 1996, Vol. 113(1), DOI: https://doi.org/10.7767/zrgra.1996.113.1.64, pp. 88-131. See also G. 1,21: Praeterea minor triginta annorum seruus manumissus potest ciuis Romanus fieri, si ab eo domino, qui soluendo non erat, testamento eum liberum et heredem relictum [...... vv. 24 nunc legi non possunt ...... J. However, the situation was different when the owner wanted to free his slave, who was less than 30 years old, to make him or his heir, but to the inheritance without any debts. Then the act required that such a slave had already completed the required legal age. Cf. G. 2,276: Item cum senatus consulto prohibitum sit proprium servum minorem annis XXX liberum et heredem instituere, plerisque placet posse nos iubere liberum esse, cum annorum XXX erit, et rogare, ut tunc illi restituatur hereditas. See also R. Świrgoń-Skok, Zagadnienie obywatelstwa niewolnika ustanowionego spadkobierca $w$ testamencie rzymskim, „Humanistyczne Zeszyty Naukowe Prawa Człowieka" 2014, nr 17, pp. 201-214.

7 W. Osuchowski, Zarys rzymskiego prawa prywatnego, Warszawa 1971, p. 228. 
marriage, and besides, he did not have any political rights ${ }^{8}$. According to the Latin phrase Latini Iuniani, they lived like free people, but they died like slaves ${ }^{9}$ (vivunt quasi ingenui, moriuntur ut servi).

Considering the above legal position of Junian Latins, the phrase used in the introduction of this article seems accurate, that it was a category of people located in "a legal vacuum". This situation was the effect of the law more widely known as lex Iunia Norbana or simply as lex Iunia ${ }^{10}$. The generally accepted date of this act is 19 A.D. ${ }^{11}$, that is after the death of Octavian Augustus, during the reign of his successor, Emperor Tiberius. However, there are disputes in the literature when exactly this act was passed ${ }^{12}$. As M. Duff pointed out, there are discrepancies among researchers of the establishment date of this act (the period from 83 B.C. until 19 A.D. is discussed). The author, after careful analysis of sources and literature, limited this period to the interval between 31 B.C. and 4 A.D., at the latest by the date of the issue of the Aelia Sentia ${ }^{13}$.

Year 19 A.D. that is, the reign of Tiberius, is rather rejected in the latest literature. In the monograph devoted to freedmen H. Mouritsen ${ }^{14}$ opted for such a view,

${ }^{8}$ Cf. M. Kaser, Handbuch des Römischen Privatrechtes. Handbuch der Altertumswissenschaft. Das altrömische, das vorklassische und klassische Recht, München 1971, p. 282.

9 M. Kuryłowicz, A. Wiliński, Rzymskie prawo prywatne. Zarys wykładu, Warszawa 2016, p. 97.

${ }_{10}$ As it was indicated by W.W. Buckland, the name lex Iunia was used by classical writers, while lex Iunia Norbana appeared only once in the text from the Justinian Institutions. Cf. W.W. Buckland, The Roman Law of Slavery..., p. 534.

${ }^{11}$ See G. Rotondi, Leges Publicae Populi Romani. Elenco cronologico con una introduzione sull'attività legislativa dei comizi romani, Milano 1912, pp. 100-101; D. Mantovani, Legum multitudo e diritto privato. Revisione critica della tesi di Giovanni Rotondi, [in:] Leges publicae. La legge nell'esperienza giuridica romana. Collegio di diritto romano 2010. Cedant, a cura di Jean-Louis Ferrary, a cura di J.-L. Ferrary, Pavia 2012, p. 736. Both - G. Rotondi and D. Mantovani (who generally is arguing with Rotondi) - indicate the year 19 A.D. as the probably date of lex Iunia Norbana. It was also accepted by W.W. Buckland (The Roman Law of Slavery ..., p. 534), who stated: "[...] for A.D. 19, this has been commonly accepted as the correct date".

12 Following M. Zabłocka (Przemiany prawa osobowego..., p. 15, footnote 16): M. de Dominicis, La "Latinitas Iuniana" e la Legge Elia Senzia, "The Legal History Review" 1965, Vol. 33(4), DOI: https://doi.org/10.1163/157181965X00287, p. 572; idem, I latini iuniani nel pensiero del legislatore romano, "Annali Perugia" 1972, n. 1, p. 515, 526; idem, Les Latins Juniens dans la pensée du legislateur romain, "RIDA" 1973, Vol. 20, p. 313; G. Fabre, Li Libertus. Recherches sur les rapports patron-affranchi à la fin de la république Romaine, Roma 1981, p. 58; A.J.B. Sirks, Informal Manumission and the lex Junia, "RIDA" 1981, Vol. 28, p. 250, 273; idem, The lex Junia and the Effects of Informal Manumission and Iteration, "RIDA" 1983, Vol. 30, p. 212. See also O. Robleda, Il diritto degli schiavi nell'antica Roma, Roma 1976, p. 136, 153; W.W. Buckland, A Text-Book of Roman Law: From Augustus to Justinian, Cambridge 1963, p. 78.

${ }_{13}$ M. Duff, Freedmen in the Early Roman Empire, Cambridge 1958, pp. 210-214.

${ }^{14}$ H. Mouritsen, The Freedman in the Roman World, Cambridge 2011, p. 86, footnote 84. And there also cited: C. Venturini, "Latini facti", "peregrini" e "civitas": note sulla normativa adrianea, "BIDR" 1995-1996, Vol. 37-38, p. 219 ff.; S. Treggiari, Roman Marriage. Iusti Coniuges from the 
fairly firmly presented by M. Balestri Fumagalli ${ }^{15}$. Very interesting in this regard is the position of A. Wiliński, who stated that the lex Aelia Sentia already knew the status of a Junian Latin, but only for people who did not meet the requirements of this act (if the freedman was not 30 years old or liberating one was not 20 years old, then - according to her text - he did not become a Roman citizen). The lex Iunia Norbana, on the other hand, was to be passed later and concerned a completely different group of people ${ }^{16}$. Commenting on this view, M. Zabłocka assumed that this position seems to be the most appropriate, as indicated by the sources and then legislative tendencies ${ }^{17}$. Similarly, B. Rawson and P. Weaver indirectly agreed with A. Wiliński, acknowledging that the phrase Latini ex lege Aelia Sentia itself indicates that the law already knew this category of people, although, in their opinion, lex lunia Norbana was enacted for more than 20 years before the lex Aelia Sentia, not later, as A. Wiliński perceived $i^{18}$.

As seen from the above, it is acceptable that the category of Junian Latins and their limited legal position were shaped in the lex Aelia Sentia itself, that is in 4 A.D. during the reign of Octavian Augustus. From the point of view of the hypothesis put forward at the beginning of the present article, two factors have significance: 1) the reasons for applying the 30-year limit in this act and 2) its consequences, in particular, whether the records of not releasing slaves under 30 years of age have been respected.

The reasons for the application of the age limit of 30 years, until recently in the literature of the subject, basically were not elaborated ${ }^{19}$. The analysis of texts directly devoted to the Aelia Sentia act gives no answer to the age census adopted there. Also very widely carried out research on all age limits appearing in juridical sources of Roman law did not lead to the disclosure of other cases of the 30-year limit in private law which makes it even impossible to deduce from analogies or opposites. The conclusion from this is that the age of 30 applied in lex Aelia Sentia

Time of Cicero to the Time of Ulpian, Oxford 1991, p. 53; M. Caroll, Spirits of the Dead. Roman Funerary Commemoration in the Western Europe, Cambridge 2006, p. 189.

${ }_{15}$ M. Balestri Fumagalli, Lex Iunia de manumissionibus, Milan 1985.

16 A. Wiliński, Zur Frage von Latinern ex lege Aelia Sentia, „Zeitschrift der Savigny-Stiftung für Rechtsgeschichte: Romanistische Abteilung“ 1963, Vol. 80(1), DOI: https://doi.org/10.7767/ zrgra.1963.80.1.378, p. $378 \mathrm{ff}$.

${ }_{17}$ M. Zabłocka, Przemiany prawa osobowego..., p. 15; eadem, Polityka dynastii julijsko-klaudyjskiej wobec wyzwoleń i wyzwoleńców, „Prawo Kanoniczne” 1984, nr 1-2, p. 226.

18 B. Rawson, P. Weaver, The Roman Family in Italy: Status, Sentiment, Space, Oxford 1999, pp. 58-59.

19 With this issue dealt W.J. Kosior. Cf. W.J. Kosior, Kategorie i granice wieku ..., pp. 229-244; idem, G. 1,17 i G. 1,38. Uwagi na tle spotecznych i demograficznych uwarunkowań ustawy „Aelia Sentia”, „Łódzkie Studia Teologiczne” 2018, nr 2, p. 73 ff. 
as a formal condition for the liberation of a slave, it was a product of only this very act and it did not have any rational justification ${ }^{20}$.

The assessment of these causes also leads to some reflection, if one looks at it from the point of view of Roman demography and the length of human life, but not a citizen, just a slave. Thus, at birth, the average life expectancy of a slave ranged between 12 and 22 years. After experiencing the infancy, this length increased to 25 years, and for imperial slaves it was almost 27 years. If a slave, for example from a slave market, survived his childhood and then was sold out by his owner, his life expectancy ranged between 40 and 60 years ${ }^{21}$. Also, according to recent studies, such an average lifespan of a slave (and after the infancy) was about 25 years $^{22}$. Looking from this perspective, the statutory limit of 30 years was quite high and I think that it can be described as "prohibitive". What is more, even if we consider the above demographic arguments with the average life expectancy of a slave to be unconvincing and so the 30-year limit could have been "prohibitive" if we take into account the living conditions and, above all, the work of slaves, which resulted in the fact that after 30 years of age they already had time of their greatest activity and vitality ${ }^{23}$, and thus the economic usefulness of such slaves decreased significantly ${ }^{24}$.

The second important aspect of the Aelia Sentia law and the 30-year border problem is the question of whether these provisions have been followed ${ }^{25}$. Research in this area was carried out by G. Alföldy, who after analyzing the tombstone inscriptions revealed in Rome and on the rest of Italy, stated that about $65 \%$ of slaves were liberated before reaching the required age of 30 years, about $40 \%$ in the age range between 20 and 30 years, so only about $25 \%$ were released after crossing 30 years of age ${ }^{26}$. The views of G. Alföldy and his calculations met with criticism ${ }^{27}$, but even

${ }^{20}$ It is usually assumed that the reason for introducing the 30-year-old border was the wish that a slave would serve his master until that time, because until that age he remained in full physical strength, which he was supposed to use to work at the owner's place.

21 W.J. Kosior, G. 1,17 i G. 1,38. Uwagi na tle społecznych i demograficznych uwarunkowań..., pp. 82-83. See also E. Herrmann-Otto, Slaves and freedmen, [in:] The Cambridge Companion to Ancient Rome, ed. P. Erdkamp, Cambridge 2013, p. 68; idem, Ex Ancilla Natus. Untersuchungen zu den 'Hausgeborenen'Sklaven und Sklavinnen im Westen des römischen Kaiserreiches, Stuttgart 1994, p. 248.

22 P. Hunt, Ancient Greek and Roman Slavery, Malden 2018, p. 42.

23 W. Scheidel, The Roman slave supply, 2007, www.princeton.edu/ pswpc/pdfs/scheidel/050704. pdf [access: 10.08.2019], p. 6.

24 A.R. Birley, The People of Roman Britain, Berkeley-Los Angeles 1979, p. 147.

25 Cf. W.J. Kosior, G. 1,17 i G. 1,38. Uwagi na tle społecznych i demograficznych uwarunkowań..., pp. 85-90.

26 G. Alföldy, Die Freilassung von Sklaven und die Struktur der Sklaverei in der römischen Kaiserzeit, „Rivista storica dell'Antichità“ 1972, n. 2, pp. 107-113. See also S. Dixon, Childhood, Class and Kin in the Roman World, London-New York 2001, p. 103.

27 P. Garnsey, Child-rearing in ancient Italy, [in:] Cities, Peasants and Food in Classical Antiquity. Essays in Social and Economic History, ed. W. Scheidel, Cambridge 1998, pp. 253-271; W.V. 
his adversaries admitted that the release of slaves before they reached 30 years was not uncommon ${ }^{28}$. L. Schumacher also confirmed this ${ }^{29}$. We can, therefore, assume that the 30-year-old limit introduced in the described act was not a real blockade for the release of slaves below this age. Perhaps it was also influenced by the total lack of sanctions for the owner who granted freedom before the slave reached the required age and the slave himself could not resist the liberation. In this subject, G. Alföldy spoke quite enigmatically, saying that, i.a., the law in question neither could nor intended to limit the universal practice of liberating slaves, adding that it was just the opposite because in the first two centuries of the empire, the owners commonly were liberating their slaves ${ }^{30}$. This can also be confirmed by the latest analyzes of tombstone inscriptions carried out by M. Hirt, who noticed that about one thousand three hundred inscriptions were kept dedicated to the freedmen who died at the age of $30^{31}$, and the last majority of them were Junian Latins ${ }^{32}$.

To sum up the above considerations, it can be noticed, that in 4 A.D. Octavian Augustus led to pass the law - lex Aelia Sentia - which intention was to limit the scale of slave liberation, among others, by requiring that the slave to be liberated should be at least 30 years old. At the same time, the same act (or another one issued several years later) sanctioned that violation of this requirement resulted in granting freedom, but not in the rank of a Roman citizen, but - especially for the purposes of this law created - in the rank of a Junian Latin, who was significantly limited in its rights. The limit of 30 years was, in fact, a barrier because it exceeded the average lifespan of a slave. No sanctions were foreseen for owners who released younger slaves. All this led to the fact that slaves under 30 were massively liberated, which resulted in the funding of the Junian Latins group.

Harris, Towards a Study of the Roman Slave Trade, "Memoirs of the American Academy in Rome. The Seaborne Commerce of Ancient Rome: Studies in Archaeology and History" 1980, Vol. 36, DOI: https://doi.org/10.2307/4238700, pp. 117-140.

${ }^{28}$ P. Garnsey, Independent freedmen and the economy of Roman Italy under the Principate, [in:] Cities, Peasants and Food in Classical Antiquity..., p. 31.

${ }^{29}$ L. Schumacher, Niewolnictwo antyczne, Poznań 2005, p. 279.

${ }^{30}$ G. Alföldy, Historia społeczna starożytnego Rzymu, Poznań 1991, p. 188.

${ }^{31}$ Recently, the indicated subject was elaborated by O. Schipp who based on the tombstone of a man named Gaius Seccius Corinthus. See O. Schipp, Der großzügige Patron Gajus Seccius. Eine Fallstudie zur Lex Aelia Sentia und ihren Folgen für unter 30-jährige Freigelassene, "Mainzer Zeitschrift" 2017, Bd. 112, pp. 15-27 (especially p. 20 ff).

${ }^{32}$ See M. Hirt, In search of Junian Latins, "Historia" 2018, Vol. 67(3), DOI: https://doi. org/10.25162/historia-2018-0011, pp. 288-312. 
III.

The second act described in this article is lex Visellia. It provided for the possibility of Junian Latin to apply for the Roman citizenship, under the condition of serving six years of military service in cohortes vigilum, a paramilitary organisation which was basically a Roman fire brigade and night police ${ }^{33}$. We learn about it from the Gaius's message:

G. 1,32b: Praeterea ex lege Visellia tam maiores quam minores XXX annorum manumissi et Latini facti ius Quiritium adipiscuntur, id est funt ciues Romani, si Romae inter vigiles sex annis militauerint. postea dicitur factum esse senatus consultum, quo data est illis ciuitas Romana, si triennium militiae expleuerint ${ }^{34}$.

The jurist pointed out that under the Visellia act, having both more and less than 30 years, who after the liberation became Junian Latins, they could get the law of Quirites, that is, they could become Roman citizens if they had served six years of military service in Rome as vigiles. Gaius also added that in later years this requirement was reduced to three years of service. Reading this message, it is impossible to refuse the position of E. Koops, who noticed that the solution adopted in lex Visellia was directed to the Junian Latins and specifically to former slaves who, due to the violation of the statutory trigger rules, found themselves in this personal group ${ }^{35}$.

To answer the question about why this statutory record was directed to the Junian Latins, it is supposed to deliberate the vigiles ${ }^{36}$ in ancient Rome. The formal beginnings of the organisation militia vigilum should be sought in 6 A.D. when Octavian Augustus decided to create seven vigil cohorts (cohortes vigilum), where each had a thousand people to serve as a specialised fire brigade in Rome ${ }^{37}$. At the

${ }_{33}$ Cf. M. Jaczynowska, Historia starożytnego Rzymu, Warszawa 1983, p. 217.

${ }^{34}$ Epit. Ulp. 3,5: Militia ius Quiritium accipit Latinus, si inter vigiles Romae sex annis militaverit, ex lege Visellia. Postea ex senatus consulto concessum est ei, ut, si triennio inter vigiles militaverit, ius Quiritium consequatur.

${ }^{35}$ E. Koops, Masters and Freedmen: Junian Latins and the Struggle for Citizenship, [in:] Integration in Rome and in the Roman World: Proceedings of the Tenth Workshop of the International Network Impact of Empire (Lille, June 23-25, 2011), eds. G. de Kleijn, S. Benoist, Leiden-Boston 2014, p. 123.

${ }^{36}$ See, in particular: P.K. Baillie Reynolds, The Vigiles of Imperial Rome, Oxford 1926; J.S. Rainbird, The Fire Stations of Imperial Rome, "Papers of the British School at Rome" 1986, Vol. 54, DOI: https://doi.org/10.1017/S0068246200008874, pp. 147-169; P. Grabowski, Strażacyz Wiecznego Miasta, „Przegląd Pożarniczy” 2005, nr 12, pp. 28-29. The doctoral dissertation was also devoted to the subject of vigiles. See J.S. Rainbird, The Vigiles of Rome, Durham 1976.

37 E. Dąbrowa, Organizacja armii rzymskiej w okresie Wczesnego Cesarstwa, [in:] Starożytny Rzym we współczesnych badaniach. Państwo - społeczeństwo - gospodarka. Liber in memoriam Lodovici Piotrowicz, red. J. Wolski, T. Kotula, A. Kunisz, Kraków 1994, p. 118. See also G.N. Daugherty, The Cohortes Vigilum and the Great Fire of 64 AD, "The Classical Journal" 1992, Vol. 87(3), p. $229 \mathrm{ff}$. 
head of this organisation became praefectus vigilum ${ }^{38}$. It may raise doubts whether vigiles were a part of the Roman army because Tacitus did not include them in the military list ${ }^{39}$. However, as noted by J.S. Rainbird ${ }^{40}$, vigiles were organised like the rest of the army, and all disputes should be ended with a fragment of Ulpianus' ${ }^{41}$ opinion, who directly pointed: Item vigiles milites sunt [...]. An indirect position is proposed by E. Wipszycka defining vigiles as a paramilitary organisation ${ }^{42}$.

From the very beginning, this is from calling vigiles to life, there was a problem with people willing to serve there. According to P.K. Baillie Reynolds, this was due to the fact that the service was very exhausting, with no prospects for promotion, nor enjoyed public appreciation ${ }^{43}$. What is more, vigiles' wages were also much lower than in the case of other formations ${ }^{44}$. As determined by J.S. Rainbird, the initial staffing level of the cohorts was filled only in about $54 \%$ and if that was not enough, about $8 \%$ of vigiles departed from service every year ${ }^{45}$.

The remedy in this situation was to be passed by lex Visellia, whose main purpose was to attract those willing to join the formation of vigiles. For this purpose, a gratuity in the form of the acquisition of Roman citizenship was provided for six years of service. Of course, this offer was not addressed to citizens, but to free people who were not cives Romani. Therefore, the natural target group was the Junian Latins ${ }^{46}$. Also, historical sources confirm that cohortes vigilum were created just by such freedmen; wrote even about it Suetonius ${ }^{47}$ and Dio Cassius ${ }^{48}$.

${ }^{38}$ P. Kołodko, The Powers and Significance of the Prefect of the 'Vigiles'('Praefectus Vigilum') in Ancient Rome, ,Zeszyty Prawnicze UKSW” 2012, nr 4, DOI: https://doi.org/10.21697/zp.2012.12.4.10, pp. 199-214. See also D. 1,15,3, pr.: Paulus libro singulari de officio praefecti vigilum; Nam salutem rei publicae tueri nulli magis credidit convenire nec alium sufficere ei rei, quam Caesarem. Itaque septem cohortes oportunis locis constituit, ut binas regiones urbis unaquaeque cohors tueatur, praepositis eis tribunis et super omnes spectabili viro qui praefectus vigilum appellatur.

${ }^{39}$ Cf. Tacitus, Annales 4,5. Cf. Cornelii Taciti Annalium ab excessu divi Augusti libri, ed. Ch.D. Fisher, Oxford 1906, p. 134.

40 J.S. Rainbird, The Vigiles..., p. 215.

${ }^{41}$ Cf. D. 37,13,1,1, Ulpianus libro 45 ad edictum.

42 See Vademecum historyka starożytnej Grecji i Rzymu, red. E. Wipszycka, t. 1, Warszawa 1985, p. 197.

${ }^{43}$ P.K. Baillie Reynolds, op. cit., p. 66.

${ }^{44}$ Most likely, it was 150 denarii a year in comparison with the 225 denarii that legionnaires received. Cf. J.S. Rainbird, The Vigiles ..., pp. 240.

45 Ibidem, p. 217, 445.

${ }^{46}$ More: ibidem, pp. 222-229. See also K.M.T. Atkinson, op. cit., p. 364; C. Ricci, Security in Roman Times: Rome, Italy and the Emperors, New York 2018, p. 124; K. Verboven, The Freedman Economy of Roman Italy, [in:] Free At Last!: The Impact of Freed Slaves on the Roman Empire, eds. T. Ramsby, S. Bell, London 2012, p. 89.

47 Suetonius, Divus Augustus 25,2; libertino milite, praeterquam Romae incendiorum causa et si tumultus in grauiore annona metueretur [...] - C. Suetonii Tranquilli Opera, Vol. I, Libri V, ed. M. Ihm, Leipzig 1907, pp. 63-64.

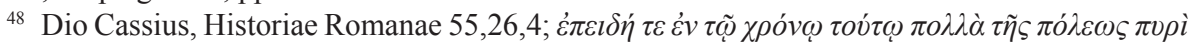

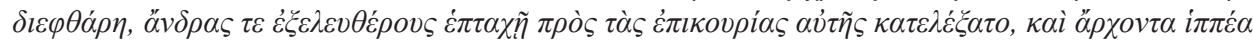


Previously deliberately omitted in this article, the issue was the date of the adoption of lex Visellia. It is generally accepted that it was 24 A.D. for the consulate of Lucius Visellius Varro and the time of the reign of Emperor Tiberius. The law was also named after the acting consul. However, another date - as the only one in the literature - was admitted by K.M.T. Atkinson indicating that the hypothetically lex Visellia could have been passed during the lifetime of Octavian Augustus in 12 A.D. The researcher admitted this possibility through the prism that this year the consulate was held by Gaius Visellius Varro (father of the above-mentioned Lucius $)^{49}$. What is important in the literature was to associate the date of 24 A.D., with these records lex Visellia, which restricted the freedmen from access to the state of the equites and the ability to occupy positions in the municipalities ${ }^{50}$, referred to in C. 9,21, $1^{51}$. Therefore, the question should be asked whether it is possible to talk about the fact that two acts of the same name were passed. This possibility was indirectly allowed by S.H. Rutledge, who wrote about two acts ${ }^{52}$, one defined as lex Visellia de iure Quiritium Latinorum qui inter vigiles militaverant and the second lex Visellia de poenis libertinorum, qui ingenuorum honores usurpabant, both of them are associated with the date 24 A.D. ${ }^{53}$ In such a situation, the very distinction between these acts when associated with the view of K.M.T. Atkinson, at least hypothetically, could form the basis of the hypothesis, according to which there were two Viselliae leges, which divided twelve years of difference.

To summarize the above, it can be noted that in 6 A.D. Octavian Augustus called to life a formation of vigiles specialised in putting out fires, which, however, struggled with the problem of recruits from the very beginning almost half of the cohort's staffing level was not fulfiled. For this purpose, in the times of Octavian

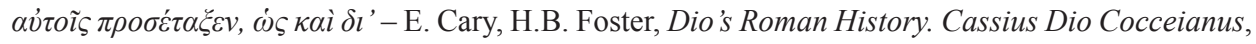
Vol. VI (Book LV), New York 1955 (reprint), p. 462.

${ }^{49}$ K.M.T. Atkinson, op. cit., p. 364.

${ }^{50}$ Cf. W.L. Westermann, The Slave Systems of Greek and Roman Antiquity, Philadelphia 1955, p. 90; D. Borbonus, Columbarium Tombs and Collective Identity in Augustan Rome, Cambridge 2014, p. 138.

${ }^{51}$ C. 9,21,1, Imperatores Diocletianus, Maximianus: Lex Visellia libertinae condicionis homines persequitur, si ea quae ingenuorum sunt circa honores et dignitates ausi fuerint attemptare vel decurionatum adripere, nisi iure aureorum anulorum impetrato a principe sustentantur. Tunc enim quoad vivunt imaginem, non statum ingenuitatis obtinent et sine periculo ingenuorum etiam officia peragunt publica. 1. Qui autem libertinus se dicit ingenuum, tam de operis civiliter quam etiam lege Visellia criminaliter poterit perurgueri: in curiam autem se immiscens damno quidem cum infamia adficitur: muneribus vero personalibus in patria patroni, quae congruunt huiusmodi hominibus, singulos pro viribus adstrictos esse non dubium est. See also C. 6,21,4,1 and C. 7,4,5.

${ }^{52}$ In the literature a mention can be found about the third law called lex Visellia, namely lex Visellia de cura viarum. G. Rotondi (op. cit., p. 97, 367) indicates the date of its adoption as 72 B.C. C. Williamson (The Laws of the Roman People: Public Law in the Expansion and Decline of the Roman Republic, Ann Arbor 2005, p. 456) is in favor of 69 B.C.

53 S.H. Rutledge, Imperial Inquisitions: Prosecutors and Informants from Tiberius to Domitian, London-New York 2001, p. 284. 
Augustus in 12 A.D. (or during the reign of Emperor Tiberius in 24 A.D.), lex Visellia was enacted, which was to encourage the Latin Junians to serve as vigils for six years in exchange for receiving the Roman citizenship.

IV.

At this point, it is necessary to return to the hypothesis put forward in the introduction and to try to answer the question about the servile role of the age limit of 30 years in relation to the legal concept which was the statutory encouragement of the Junian Latins to serve in the paramilitary organisation of vigiles.

The above-mentioned K.M.T. Atkinson encouraged a joint view on this issue, which is in the foreground among the causes of the reform of the liberation carried out by Octavian Augustus, she has just put out problems with those who were eager for the army, in particular, the cohortes vigilum. The researcher pointed out the general recruitment crisis in ancient Rome, which began in the 29 and 28 A.D. when a large number of citizens were demilitarized ${ }^{54}$. In addition, as emphasised by A. Passerini ${ }^{55}$, in 26 B.C. there was a problem with maintaining the number of praetorian guard cohorts, which were partly located in Gaul, Macedonia and Mauritania, which forced the search for volunteers from outside the legionnaires. In this state of affairs, the necessity of finding seven thousand men ready to serve as vigiles in Rome appeared as a considerable difficulty, especially since this function was neither well paid nor prestigious, while the duties of extinguishing fires and night watch in a city of around one million inhabitants ${ }^{56}$ were very difficult and tiring. Naturally, the question posed is whether the problem of recruiting citizens could not be used by peregrines, i.e. foreigners. Well, no, because they mostly served as auxiliari, in provincial formations supporting the main legionnaire units ${ }^{57}$. In this situation, another group of volunteers willing to serve in the vigil cohorts was needed.

The view has already been expressed in the literature that such a group was just the group of Junian Latins. A.N. Sherwin-White expressed this most clearly, pointing out that the main purpose of Junian Latins was to provide recruits ${ }^{58}$. In this situation, it is impossible to resist the impression that this social category was created in an artificial way, and in principle only for one purpose. This artificiality can be demonstrated by the lack of historical or geographical justification for their existence, as was the case

${ }^{54}$ K.M.T. Atkinson, op. cit., pp. 363-367.

55 A. Passerini, Le Coorti Pretorie, Roma 1939, p. 45.

56 P.J. Aicher, Rome Alive: A Source-Guide to the Ancient City, Vol. 1, Wauconda 2008, p. 215.

${ }^{57}$ K.M.T. Atkinson, op. cit., p. 364.

58 A.N. Sherwin-White, The Roman Citizenship, Oxford 1973, p. 98; K.M.T. Atkinson, op. cit., p. 363. 
with Latini prisci (veteres), that is ancient Latins originating from the municipalities included in the Latin League compound, or Latini coloniarii, originating from the Italian and provincial colonies. Evidently, therefore, Latini iuniani was a group created by law and for a given need ${ }^{59}$. It is difficult to look for rational reasons for creating a category, which included only former slaves who were given freedom, but with a significant limitation of their legal position and an additional threatened property, which after their death was to return to former owners. It is true that we can try to justify this because after all, not all freed slaves became such Latins, but only those who were liberated in violation of statutory provisions, but these requirements were actually prohibitive. Therefore, I think that the words quoted above, vivunt quasi ingenui, moriuntur ut servi, can only confirm my view, that the Junian Latins were a social group located in "a legal vacuum".

In the light of all the above considerations, the naturally asked question is whether these three stages - this is: (1) introducing a prohibitive statutory limitation of slave releases under the age of 30, (2) bringing in this way to create an artificial social group of the Junian Latins while limiting their legal position and (3) the creation of a statutory offer directed only at Junian Latins who in exchange for military service were to receive Roman citizenship they did not belong to one legal and political concept of Octavian Augustus. Another issue is whether the concept was thought out from the beginning, or maybe the above-mentioned situations over time became elements of the puzzle that the first princeps decided to use.

Let us consider this concept from chronological point of view. In 4 A.D. lex Aelia Sentia was passed which, among other things, required that a fully-liberated slave should be at least 30 years old. Full effectiveness was to rely on receiving Roman citizenship. The applied age limit did not have any rational justification, and moreover it exceeded the average lifespan of a slave, which then was about 25 years old and also at the stage of life, when its economic usefulness decreased significantly. This law in no way sanctioned the owners who liberated their slaves below this age and they themselves could not contradict it. At the same time (with the acceptance of A. Wilinski's view) are introduced the rules according to which every slave liberated below this border became a Junian Latin, a free person, but significantly limited in his rights.

Subsequently, in 6 A.D. a paramilitary cohortes vigilum organisation in the number of seven thousand vigiles was established and was intended for fighting fires and night watch in Rome. This formation was not prestigious or well paid, which in the era of the general recruitment crisis of the Roman army resulted in the fact that more than half of the staffing level of this service was not fulfiled. There was no possibility that its ranks would be joined by citizens or peregrines.

59 The group of Junian Latins was finally abolished by emperor Justinian. Cf. M. Kaser, op. cit., p. 281 and sources C. 7,6,1,6-7. 
In 12 A.D. (with the view of K.M.T. Atkinson) during the period of the consulate of Gaius Visellius Varro, the lex Visellia de iure Quiritium Latinorum qui inter vigiles militaverant was established, which was directly addressed to the social group of Junian Latins formed six years earlier, offering them Roman citizenship in exchange for a six-year service as vigils ${ }^{60}$. Latins, with the prospect that after their deaths property will be lost to the benefit of former owners, they decided to supply the ranks of vigiles ${ }^{61}$.

If we include the period of the reign of Octavian Augustus (from 27 B.C. to 14 A.D.) to all this, then we can assume that princeps by Roman law (and on the occasion of the age limit applied) he skillfully created a situation that he could use for political purposes.

It is also worth noting that the strong point of this hypothesis is also the fact that even with the rejection of the views of A. Wilinski and K.M.T. Atkinson regarding the issued laws and their dates, this view of the planned legal and political concept is also to be defended, but with the difference that its authorship should then be attributed to the successor of Octavian Augustus, Emperor Tiberius, who in his policy tried to refer to his predecessor ${ }^{62}$. In such a situation, the merit of the first princeps was the adoption of the Aelia Sentia law and the creation of vigil cohorts. The idea of creating a legally flawed social group of the Junian Latins and using them to serve as vigiles in exchange for granting Roman citizenship would be the work of Tiberius. At the time, during the reign of his rule (from 14 A.D. to 37 A.D.), it was supposed to be the adoption of lex Iunia Norbana in 19 A.D. and lex Visellia in 24 A.D.

\section{V.}

In this article, I tried to carry out an analysis that could confirm or deny that in the Aelia Sentia act established in 4 A.D. the age limit of 30 years was significant for the legal and political concept, which was supposed to lead to the creation of a new social group of the Junian Latins located in "a legal vacuum", the purpose

${ }^{60}$ It is worth noting that the idea of awarding certain profits in exchange for military service was already known, and more precisely was presented in a source known as Tabula Heracleensis. As we read in TH. 11,98-107, who was under the age of 30, could not apply, cover, or perform in the town of Heraclea, a colony or aprefecture of a duumvir, quattuorvir or other office, unless he served for 3 years in the cavalary or 6 years in the infantry. See TH. 11,98-107: quei minor annos XXX natus est erit neiquis eorum post K(alendas) Ianuar(ias) secundas in municipio colonia praefel ctura IIvir(atum) IIIIvir(atum) neve quem alium mag(istratum) petito neve capito neve gerito nisei quei eorum stipendia / equo in legione III aut pedestria in legione VI fecerit quae stipendia in castreis inve provincia maiore (m) [...]. See also B. Sitek, Tabula Heracleensis (Lex Iulia municipalis). Tekst, thumaczenie, komentarz, Olsztyn 2006, p. 57.

${ }^{61}$ J.S. Rainbird, The Vigiles..., p. 229.

${ }^{62}$ K.M.T. Atkinson, op. cit., p. 363. 
of which would basically be to serve in the army, only to get out of this void. It seems to me that the above argumentation, the chronological and thematic relationship of successive Roman statutes, confirms that the regulations contained in lex Aelia Sentia (or in lex Iunia Norbana) were basically closely connected with those introduced under the lex Visellia. It is likely that the imperial idea was to create a social category that would address the recruitment crisis in the Roman army. The age limit of liberation 30 years introduced in the first of these acts, either with an intention or in the case, led to the creation of a situation that the rulers used for the political goal of complementing the staffing of the Roman army, and more precisely of the vigiles. It should be noted, however, due to the lack of the proper sources it is difficult to give an unambiguous answer to whether the above-described law - political concept was thought out and planned from the very beginning, or maybe just be Octavian Augustus or Emperor Tiberius used the situations created by individual acts to achieve their goals. Personally, I would prefer to see in this concept a deliberately prepared plan in which Roman law was skillfully used by the emperors to create a favorable political and military situation.

\section{REFERENCES}

Aicher P.J., Rome Alive: A Source-Guide to the Ancient City, Vol. 1, Wauconda 2008.

Alföldy G., Die Freilassung von Sklaven und die Struktur der Sklaverei in der römischen Kaiserzeit, „Rivista storica dell'Antichità“ 1972, n. 2.

Alföldy G., Historia społeczna starożytnego Rzymu, Poznań 1991.

Atkinson K.M.T., The Purpose of the Manumission Laws of Augustus, "Irish Jurist" 1966, Vol. 1.

Baillie Reynolds P.K., The Vigiles of Imperial Rome, Oxford 1926.

Balestri Fumagalli M., Lex Iunia de manumissionibus, Milan 1985.

Birley A.R., The People of Roman Britain, Berkeley-Los Angeles 1979.

Borbonus D., Columbarium Tombs and Collective Identity in Augustan Rome, Cambridge 2014.

Buckland W.W., A Text-Book of Roman Law: From Augustus to Justinian, Cambridge 1963.

Buckland W.W., The Roman Law of Slavery: The Condition of the Slave in Private Law from Augustus to Justinian, Cambridge 1908.

C. Suetonii Tranquilli Opera, Vol. I, Libri V, ed. M. Ihm, Leipzig 1907.

Caroll M., Spirits of the Dead. Roman Funerary Commemoration in the Western Europe, Cambridge 2006.

Cary E., Foster H.B., Dio’s Roman History. Cassius Dio Cocceianus, Vol. VI (Book LV), New York 1955 (reprint).

Cornelii Taciti Annalium ab excessu divi Augusti libri, ed. Ch.D. Fisher, Oxford 1906.

Daugherty G.N., The Cohortes Vigilum and the Great Fire of 64 AD, "The Classical Journal" 1992, Vol. 87(3).

Dąbrowa E., Organizacja armii rzymskiej w okresie Wczesnego Cesarstwa, [in:] Starożytny Rzym we wspótczesnych badaniach. Państwo - spoleczeństwo - gospodarka. Liber in memoriam Lodovici Piotrowicz, red. J. Wolski, T. Kotula, A. Kunisz, Kraków 1994.

Dixon S., Childhood, Class and Kin in the Roman World, London-New York 2001. 
Dominicis M. de, I latini iuniani nel pensiero del legislatore romano, “Annali Perugia” 1972, n. 1.

Dominicis M. de, La "Latinitas Iuniana” e la Legge Elia Senzia, "The Legal History Review" 1965, Vol. 33(4), DOI: https://doi.org/10.1163/157181965X00287.

Dominicis M. de, Les Latins Juniens dans la pensée du legislateur romain, "RIDA" 1973, Vol. 20.

Duff M., Freedmen in the Early Roman Empire, Cambridge 1958.

Fabre G., Libertus. Recherches sur les rapports patron-affranchi à la fin de la république Romaine, Roma 1981.

Garnsey P., Child-rearing in ancient Italy, [in:] Cities, Peasants and Food in Classical Antiquity. Essays in Social and Economic History, ed. W. Scheidel, Cambridge 1998.

Garnsey P., Independent freedmen and the economy of Roman Italy under the Principate, [in:] Cities, Peasants and Food in Classical Antiquity. Essays in Social and Economic History, ed. W. Scheidel, Cambridge 1998.

Giménez-Candela T., Bemerkungen über Freilassungen in consilio, „Zeitschrift der Savigny-Stiftung für Rechtsgeschichte: Romanistische Abteilung“ 1996, Vol. 113(1),

DOI: https://doi.org/10.7767/zrgra.1996.113.1.64.

Grabowski P., Strażacy z Wiecznego Miasta, „Przegląd Pożarniczy” 2005, nr 12.

Harris W.V., Towards a Study of the Roman Slave Trade, "Memoirs of the American Academy in Rome. The Seaborne Commerce of Ancient Rome: Studies in Archaeology and History" 1980, Vol. 36, DOI: https://doi.org/10.2307/4238700.

Herrmann-Otto E., Ex Ancilla Natus. Untersuchungen zu den 'Hausgeborenen'Sklaven und Sklavinnen im Westen des römischen Kaiserreiches, Stuttgart 1994.

Herrmann-Otto E., Slaves and freedmen, [in:] The Cambridge Companion to Ancient Rome, ed. P. Erdkamp, Cambridge 2013.

Hirt M., In search of Junian Latins, "Historia" 2018, Vol. 67(3),

DOI: https://doi.org/10.25162/historia-2018-0011.

Hunt P., Ancient Greek and Roman Slavery, Malden 2018.

Jaczynowska M., Historia starożytnego Rzymu, Warszawa 1983.

Kaser M., Handbuch des Römischen Privatrechtes. Handbuch der Altertumswissenschaft. Das altrömische, das vorklassische und klassische Recht, München 1971.

Kołodko P., The Powers and Significance of the Prefect of the 'Vigiles'('Praefectus Vigilum') in Ancient Rome, ,Zeszyty Prawnicze UKSW” 2012, nr 4, DOI: https://doi.org/10.21697/zp.2012.12.4.10.

Koops E., Masters and Freedmen: Junian Latins and the Struggle for Citizenship, [in:] Integration in Rome and in the Roman World: Proceedings of the Tenth Workshop of the International Network Impact of Empire (Lille, June 23-25, 2011), eds. G. de Kleijn, S. Benoist, Leiden-Boston 2014.

Kosior W.J., G. 1,17 i G. 1,38. Uwagi na tle społecznych i demograficznych uwarunkowań ustawy „Aelia Sentia”, „,Lódzkie Studia Teologiczne” 2018, nr 2.

Kosior W.J., Kategorie i granice wieku oraz ich znaczenie w prawie rzymskim, Warszawa 2018 (unpublished doctoral dissertation).

Kuryłowicz M., Wiliński A., Rzymskie prawo prywatne. Zarys wykładu, Warszawa 2016.

Mantovani D., Legum multitudo e diritto privato. Revisione critica della tesi di Giovanni Rotondi, [in:] Leges publicae. La legge nell'esperienza giuridica romana. Collegio di diritto romano 2010. Cedant, a cura di Jean-Louis Ferrary, a cura di J.-L. Ferrary, Pavia 2012.

Mouritsen H., The Freedman in the Roman World, Cambridge 2011.

Osuchowski W., Zarys rzymskiego prawa prywatnego, Warszawa 1971.

Passerini A., Le Coorti Pretorie, Roma 1939.

Rainbird J.S., The Fire Stations of Imperial Rome, "Papers of the British School at Rome" 1986, Vol. 54, DOI: https://doi.org/10.1017/S0068246200008874.

Rainbird J.S., The Vigiles of Rome, Durham 1976.

Rawson B., Weaver P., The Roman Family in Italy: Status, Sentiment, Space, Oxford 1999. 
Ricci C., Security in Roman Times: Rome, Italy and the Emperors, New York 2018.

Robleda O., Il diritto degli schiavi nell'antica Roma, Roma 1976.

Rotondi G., Leges Publicae Populi Romani. Elenco cronologico con una introduzione sull'attività legislativa dei comizi romani, Milano 1912.

Rutledge S.H., Imperial Inquisitions: Prosecutors and Informants from Tiberius to Domitian, London-New York 2001.

Scheidel W., The Roman slave supply, 2007, www.princeton.edu/ pswpc/pdfs/scheidel/050704.pdf [access: 10.08.2019].

Schipp O., Der großzügige Patron Gajus Seccius. Eine Fallstudie zur Lex Aelia Sentia und ihren Folgen für unter 30-jährige Freigelassene,"Mainzer Zeitschrift" 2017, Bd. 112.

Schumacher L., Niewolnictwo antyczne, Poznań 2005.

Sherwin-White A.N., The Roman Citizenship, Oxford 1973.

Sirks A.J.B., Informal Manumission and the lex Junia, "RIDA" 1981, Vol. 28.

Sirks A.J.B., The lex Junia and the Effects of Informal Manumission and Iteration, "RIDA" 1983, Vol. 30.

Sitek B., Tabula Heracleensis (Lex Iulia municipalis). Tekst, thumaczenie, komentarz, Olsztyn 2006.

Świrgoń-Skok R., Zagadnienie obywatelstwa niewolnika ustanowionego spadkobierca w testamencie rzymskim, „Humanistyczne Zeszyty Naukowe Prawa Człowieka” 2014, nr 17.

Treggiari S., Roman Marriage. Iusti Coniuges from the Time of Cicero to the Time of Ulpian, Oxford 1991.

Vademecum historyka starożytnej Grecji i Rzymu, red. E. Wipszycka, t. 1, Warszawa 1985.

Venturini C., "Latini facti", "peregrini" e "civitas": note sulla normativa adrianea, "BIDR" 1995-1996, Vol. 37-38.

Verboven K., The Freedman Economy of Roman Italy, [in:] Free At Last!: The Impact of Freed Slaves on the Roman Empire, eds. T. Ramsby, S. Bell, London 2012.

Westermann W.L., The Slave Systems of Greek and Roman Antiquity, Philadelphia 1955.

Wiliński A., Zur Frage von Latinern ex lege Aelia Sentia, „Zeitschrift der Savigny-Stiftung für Rechtsgeschichte: Romanistische Abteilung“" 1963, Vol. 80(1),

DOI: https://doi.org/10.7767/zrgra.1963.80.1.378.

Williamson C., The Laws of the Roman People: Public Law in the Expansion and Decline of the Roman Republic, Ann Arbor 2005.

Zabłocka M., Polityka dynastii julijsko-klaudyjskiej wobec wyzwoleń i wyzwoleńców, „Prawo Kanoniczne" 1984, nr 1-2.

Zabłocka M., Przemiany prawa osobowego i rodzinnego w ustawodawstwie dynastii julijsko-klaudyjskiej, Warszawa 1987.

\section{STRESZCZENIE}

Na początku I w. n.e. w starożytnym Rzymie przeprowadzono szereg reform w zakresie prawa osobowego. Wówczas została uchwalona lex Aelia Sentia, która ograniczała wyzwolenie niewolników. Ponadto w tym okresie uchwalono lex Visellia, która kusiła byłych niewolników obywatelstwem rzymskim w zamian za służbę w armii. Celem niniejszego artykułu była próba ustalenia, czy można mówić o tym, że ustawy wymienione w tytule (tj. lex Aelia Sentia i lex Visellia) łączył wspólny cel i tak naprawdę część ich przepisów łącznie tworzyła jeden koncept prawny, który miał zapewnić łatwy dostęp rekrutów do nowo utworzonej paramilitarnej organizacji militia vigilum, do której - po epoce wojen domowych i ogólnym kryzysie rekrutacyjnym w armii - nie było chętnych.

Stowa kluczowe: lex Aelia Sentia; lex Visellia; vigiles; Latini iuniani 